\title{
Effect of resin type, pressing temperature and time on particleboard properties made from sorghum bagasse
}

\author{
Apri H Iswanto $^{1}$, Irawati Azhar ${ }^{1}$, Supriyanto ${ }^{2}$, Arida Susilowati ${ }^{3}$ \\ ${ }^{1}$ Major of Forestry, Faculty of Agriculture, North Sumatera University, North Sumatera, Indonesia \\ ${ }^{2}$ Department of Silviculture, Faculty of Forestry, Bogor Agricultural University, Bogor, Indonesia \\ ${ }^{3}$ Major of Agrotechnology, Faculty of Agriculture, Prima Indonesia University, North Sumatera Indonesia
}

\section{Email address:}

apriheri@yahoo.com (A. H. Iswanto), irfari@yahoo.co.id (I. Azhar), supriyanto@biotrop.org (Supriyanto), arida_iswanto@yahoo.co.id (A. Susilowati)

\section{To cite this article:}

Apri H Iswanto, Irawati Azhar, Supriyanto, Arida Susilowati. Effect of Resin Type, Pressing Temperature and Time on Particleboard Properties made from Sorghum Bagasse. Agriculture, Forestry and Fisheries. Vol. 3, No. 2, 2014, pp. 62-66. doi: 10.11648/j.aff.20140302.12

\begin{abstract}
Sorghum bicolor L Monech part Numbu as potential materials for particleboard manufacturing due to its cellulose, hemicellulose and lignin content similar with wood. The objective of the research was to determine the adhesive type, pressing temperature and time on physical and mechanical properties of particleboard made from sorghum bagasse. Size of board was $(300 \times 300 \times 10) \mathrm{mm}^{3}, 0.7 \mathrm{~g} \mathrm{~cm}^{-3}$ targeted density, $10 \%$ resin content of urea formaldehyde (UF), and Phenol Formaldehyde (PF), 7\% for Isocyanate, over all based on oven-dry particles. Furnish (mixture of particle and resin) was placed in hot press machine at temperature of $120^{\circ} \mathrm{C}$ and $130{ }^{\circ} \mathrm{C}$ for UF, $170{ }^{\circ} \mathrm{C}$ and $180{ }^{\circ} \mathrm{C}$ for $\mathrm{PF}, 150{ }^{\circ} \mathrm{C}$ and $160{ }^{\circ} \mathrm{C}$ for Isocyanate. Time of pressing in this experiment was 8 and 10 minutes. The result showed that Isocyanate resin was the best resin for resulting of physical and mechanical properties. Almost all those parameters had fulfill to the requirement of JIS A5908-2003.
\end{abstract}

Keywords: Sorghum Bagasse, Particleboard, UF, PF and Isocyanate Resin

\section{Introduction}

Sorghum plantation has been developed by SEAMEO-BIOTROP since 2009. SEAMEO-BIOTROP was also developing of technology for food, feed and energy (Supriyanto 2011, Supriyanto 2012). Sorghum plantation produce sorghum biomass $20-80$ ton/ha/3 month depending on the varieties. Thanapimmetha et al. (2011) reported that cellulose, hemicellulose and lignin content in sorghum stalk were $58.23 \%, 25.42 \%$ and $14.95 \%$ respectively. Lawal dan Ugheoke (2010) stated that sorghum stalk had $\alpha$-cellulose content amount of $48 \%$. According to that fact, sorghum stalks have potential as raw materials for particleboard manufacturing.

Utilization of sorghum bagasse to produce of particleboard will increase raw materials added value. However some problems will occur in using of agriculture materials such as voluminous (bulky) and hydrophylic properties. Bulky materials will cause to storage problems because it need bigger storage areas. Furthermore hydrophylic properties will cause the problem in dimensional stability, lower durability to termite attack, and lower mechanical properties of board when sorghum bagasse is made for particleboard.

For the first step to develop of sorghum bagasse as raw materials for particleboard, study about characteristic of materials and particleboard manufacturing technology were needed for resulting of product with superior quality. The objective of the research was to evaluate the effect of resin type, temperature and time of pressing on physical and mechanical properties of particleboard made from sorghum bagasse.

\section{Materials and Methods}

\subsection{Materials}

Sorghum bagasse were collected from SEAMEO-BIOTROP, Bogor. UF resin (UA-140) and PF resin (PA-125) were obtained from PT. Palmolite Adhesive 
Indonesia, Probolinggo, East Java. Furthermore Isocyanat resin (H3M type) was obtained from PT. Polichemi Oshika, Jakarta. To obtain the best particleboard made of sorghum bagasse, the particleboard manufacturing condition was made available as shown in Table 1.

Tabel 1. Particleboard manufacturing condition.

\begin{tabular}{|c|c|c|}
\hline No & & Condition \\
\hline 1 & Board size & $(300 \times 300 \times 10) \mathrm{mm}^{3}$ \\
\hline \multirow{2}{*}{$\begin{array}{l}2 \\
3\end{array}$} & Density target & $0.7 \mathrm{~g} \mathrm{~cm}^{-3}$ \\
\hline & & UF, PF, Isocyanate \\
\hline \multirow[b]{2}{*}{4} & Adhesive & $\begin{array}{l}\text { Resin Content: } \\
\text { UF }(10 \%), \text { PF }(10 \%) \text {, Isocyanate }(7 \%) \\
\text { Solid content: } \\
\text { UF }(63 \%), \text { PF }(50 \%) \text {, Isocyanate }(97 \%)\end{array}$ \\
\hline & & $\begin{array}{l}\text { Particle size: } 14.38 \mathrm{~mm} \text { (length), } 3.25 \\
\mathrm{~mm} \text { (width), } 0.57 \mathrm{~mm} \text { (thick) }\end{array}$ \\
\hline \multirow[b]{4}{*}{5} & Sorghum bagasse & Slenderness ratio: 27.77 \\
\hline & & Aspect ratio: 4.69 \\
\hline & & Moisture content: $4 \%$ \\
\hline & Hot press & $\begin{array}{l}\text { Temperature: } 120^{\circ} \mathrm{C} \text { and } 130{ }^{\circ} \mathrm{C} \text { (UF), } \\
170{ }^{\circ} \mathrm{C} \text { and } 180{ }^{\circ} \mathrm{C}(\mathrm{PF}), 150{ }^{\circ} \mathrm{C} \text { and } \\
160{ }^{\circ} \mathrm{C} \text { (Isocyanat) }\end{array}$ \\
\hline \multirow[b]{3}{*}{6} & & Time: 8 and 10 minute \\
\hline & & Pressing: $25 \mathrm{~kg} \mathrm{~cm}^{-2}$ \\
\hline & Pressing Schedule & One step pressing schedule \\
\hline
\end{tabular}

\subsection{Methods}

\subsubsection{Particleboard Manufacturing}

Single layered particleboard was produced with the size of $(300 \times 300 \times 10) \mathrm{mm}^{3}$ and the density target was $0.7 \mathrm{~g} \mathrm{~cm}^{-3}$. Rotary drum blender was used for mixing particles and adhesive. Furnish then placed in hot pressed. Three boards were prepared for each treatment.

\subsubsection{Determination of Physical and Mechanical Properties}

Prior to physical and mechanical analysis, specimens were conditioned for 7 days at room temperature. The board quality was assessed using parameters on density, moisture content (MC), water absorption (WA), thickness swelling (TS), modulus of rupture (MOR) and modulus of elasticity (MOE) in bending, and internal bond (IB). The dimension of specimens for evaluation in density and $\mathrm{MC}$ of boards were $(100 \times 100) \mathrm{mm}^{2}$. The specimens were weighed immediately after oven-dried at $103 \pm 2{ }^{\circ} \mathrm{C}$ until they reached constant weight. For WA and TS tests, the dimension of specimens was $(50 \times 50) \mathrm{mm}^{2}$. The specimens were also weighed immediately after oven-dried. Average thickness was determined by taking several measurements at specific locations. After 24 hours of submersion, specimens were dripped and wiped for cleaning of any surface water, the weight and thickness of specimens were measured. Mechanical properties (MOE, MOR, and IB) were tested by using universal testing machine (UTM) equipped with a load cell with a capacity of $10,000 \mathrm{~N}$. The dimension of specimens in bending tests was $(200 \times 50) \mathrm{mm}^{2}$. While for IB test, the dimension of specimens was $(50 \times 50) \mathrm{mm}^{2}$. Evaluation of MOE, MOR, and IB parameters were performed at $28{ }^{\circ} \mathrm{C}$ and $60 \%$ R.H. The crosshead speed was adjusted to speed at $10.00 \mathrm{~mm} \mathrm{~min}^{-2}$.

\section{Results and Discussions}

\subsection{Physical Properties}

Density of particleboard made from sorghum bagasse was $0.68-0.81 \mathrm{~g} \mathrm{~cm}^{-3}$ (Figure 1).

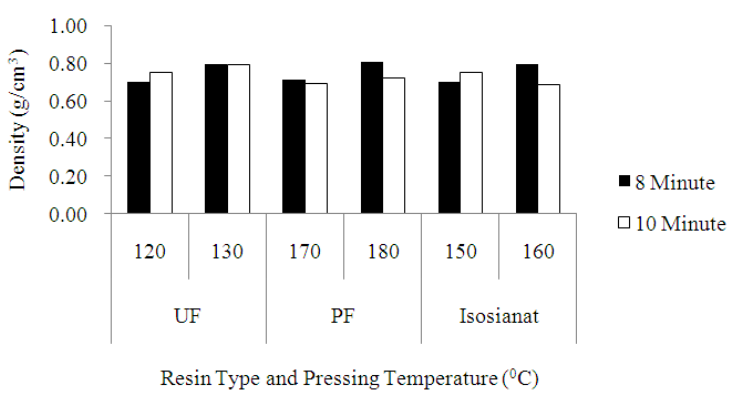

Fig 1. Density of particleboard.

Several factors that influencing of board density were wood density, pressing pressure, particle quantity in mat, resin content, and other additive (Kelley 1997). The density value in this research had fulfill of JIS A 5908- 2003 (JSA 2003). This standard requires of density value between 0.4 to $0.9 \mathrm{~g} \mathrm{~cm}^{-3}$. Bowyer et al. (2003) stated that density of particleboard is higher than the original material components, due to resin weight, additive, and pressure during manufacturing.

MC of particleboard made from sorghum bagasse was $2.92-11.06 \%$ (Figure 2).

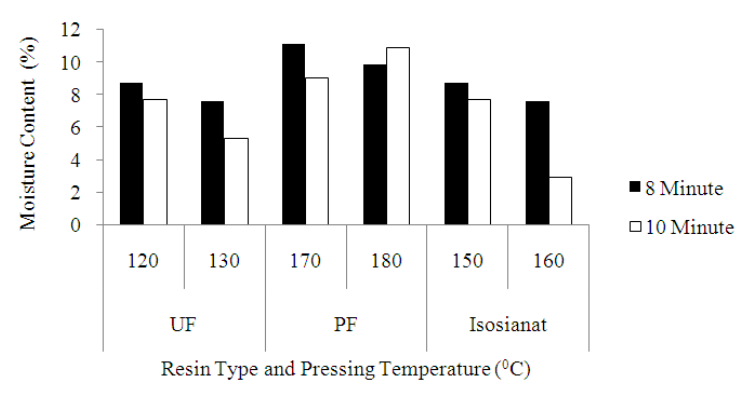

Fig 2. Moisture content of particleboard.

MC value in this research was influenced by density and particle porosity. Particleboard in lower density will cause of water or water vapor more easily to be absorbed or released into particleboard. Figure 2 showed that the increase in pressing temperature at the same time or the increase of pressing time at the same temperature in UF, PF and Isocyanate resin will reduce the MC of particleboard. Similar research was conducted by Heebink et al. (1972), decreasing pressing time at the same temperature caused the 
increase in MC. PF resin had the highest MC value compared to UF and Isocyanate resin. It was presumed that sorghum bagasse had acid properties ( $\mathrm{pH}$ 5.78), while PF resin is an adhesive having optimum performance in alkali condition. Several factors that influencing of MC are particle $\mathrm{MC}$ and environment condition during particleboard conditioning. Maloney (1993) stated that initial MC of raw material is one of important factor to determine of $\mathrm{MC}$ in particleboard produced. The MC of particleboard made of sorghum bagasse had fulfill of JIS A 5908-2003 (JSA 2003) that requirement of $\mathrm{MC}$ is $5-13 \%$.

WA value of particleboard made from sorghum bagasse was 40.77 - $124.33 \%$ (Figure 3).

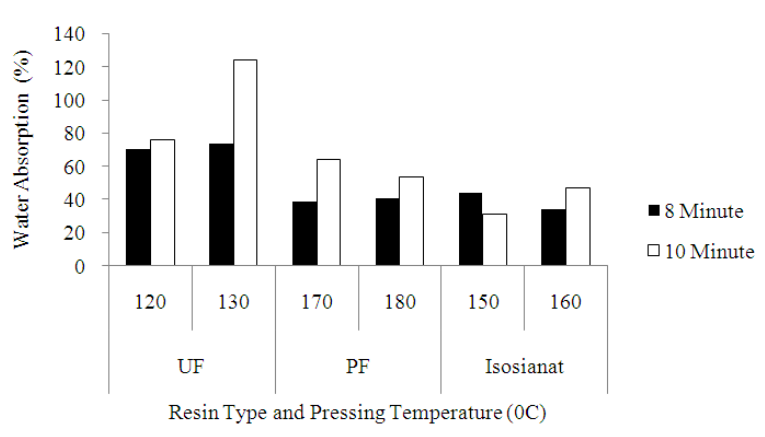

Fig 3. Water absorption value of particleboard.

UF resin resulted the highest WA value compared to PF and Isocyanate resin because UF belongs to interior adhesive type (Youngquist 1999) for indoor application, UF has low resistant to weather and moisture. Winandy \& Krzysik (2007) reported that increasing of pressing temperature and time does not resist of medium density fiberboard (MDF) to absorb of water. Hemicelluloses is the most responsible to WA if compared to cellulose and lignin.

TS of particleboard made from sorghum bagasse was 6.82 $-62.14 \%$ (Figure 4 ).

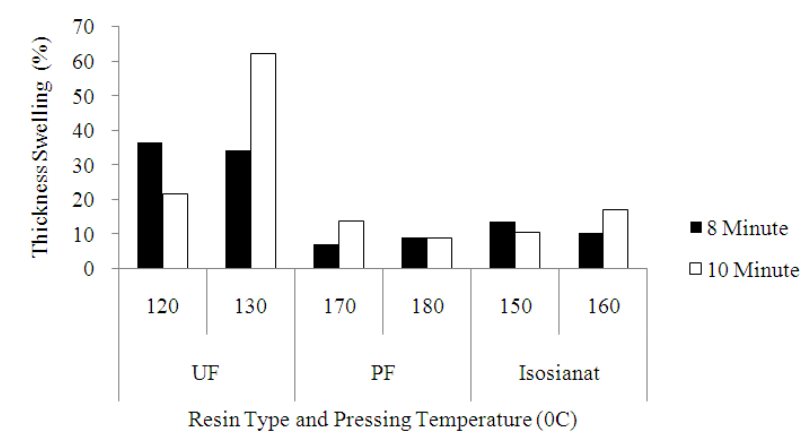

Fig 4. Thickness swelling value of particleboard.

UF resin resulted highest TS compared to $\mathrm{PF}$ and Isocyanate resin. For UF resin, the increase of pressing temperature and time caused the increase in TS value. It was caused by acidic properties of sorghum bagasse. The high temperature $\left(130^{\circ} \mathrm{C}\right)$ for longer time (10 minutes) will cause of over curing on UF resin, so that will be resulting of lowering in bonding strength. Guler et al. (2008) reported that TS of wood panel were influenced by quantity and distribution of adhesive, MC of furnish, furnish compatibility, chemical composition of furnish, etc. TS value does not fulfill of JIS A5908-2003 (JSA 2003) that requirement of maximum TS value is $12 \%$.

\subsection{Mechanical Properties}

MOE value of particleboard made from sorghum bagasse was $9700-37000 \mathrm{~kg} \mathrm{~cm}^{-2}$ (Figure 5).

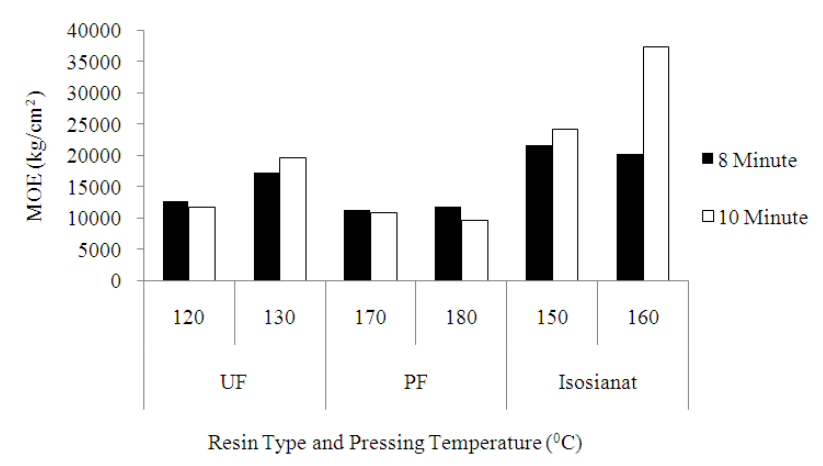

Fig 5. MOE of Particleboard.

The increasing of pressing temperature will be able to increase of MOE value for all adhesives. Malanit et al. (2009) reported that the high temperature caused of increasing resin bonding for resulting better strength. At the low temperature and in short time of pressing will cause of pre-curing of adhesive, while at the high temperature for longer time will cause of adhesive over-curing. Pre and over-curing will reduce bonding strength of particleboard. Maloney (1993) stated that there are several factors that influence of MOE value such as resin type, resin content, adhesive bonding, and fiber length. PF resin had the lowest MOE value compared to UF and Isocyanate resin because of its acidic properties of sorghum bagasse in which resulted of weakening in adhesive bonding strength. MOE for Isocyanate resin had fulfill of JIS A 5908-2003 (JSA 2003) that requirement of minimum MOE value is $20400 \mathrm{~kg} \mathrm{~cm}^{-2}$.

MOR value of particleboard made from sorghum bagasse was $52-264 \mathrm{~kg} \mathrm{~cm}^{-2}$ (Figure 6).

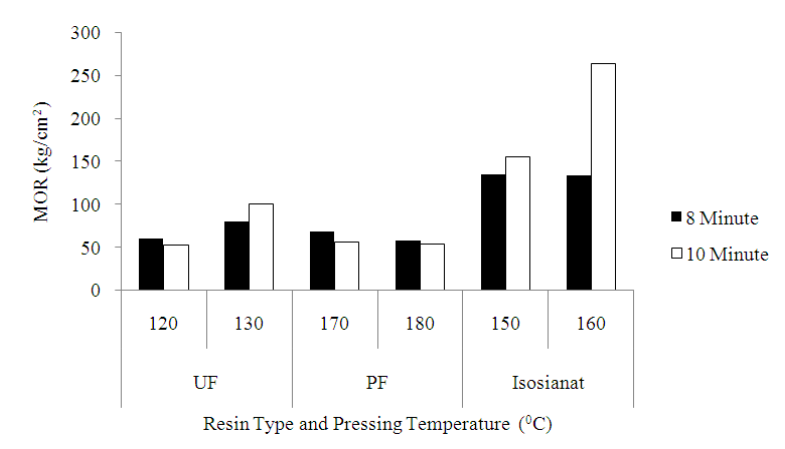

Fig 6. MOR of particleboard.

MOR trend was relatively in the similar trend with MOE 
value. The increase of pressing temperature and time caused the increase of MOR value. Isocyanate resin produced the best MOR value compared to UF and PF. Maloney (1993) stated that one of factors that influencing the MOR value is particle geometry. The slenderness and aspect ratio of sorghum bagasse were 27.8 and 4.69, respectively. Particle with high slenderness ratio will be easier to be oriented to increase of board strength, consequently it needs a few resin in the surface area for particle bonding. In addition to slenderness ratio, aspect ratio was necessary to obtain better board orientation (Maloney 1993). MOR for Isocyanate resin and UF resin had fulfill of JIS A 5908-2003 that requirement of minimum MOR values is $80 \mathrm{~kg} \mathrm{~cm}^{-2}$.

IB value of particleboard made from sorghum bagasse was $0.3-8 \mathrm{~kg} \mathrm{~cm}^{-2}$ (Figure 7).

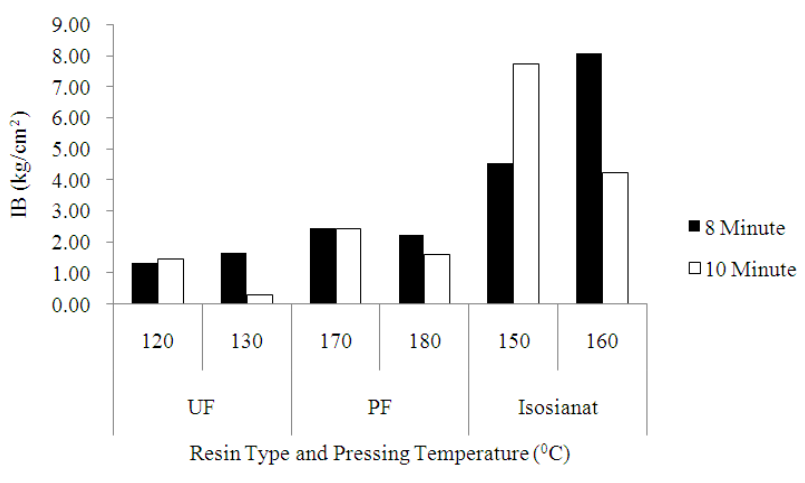

Fig 7. IB of particleboard.

The increase of pressing temperature and time caused the increase of IB value, but in higher temperature for longer time caused of reducing the IB. This condition was caused by over-curing of resin. Nemli (2002) reported that the increase of pressing temperature, time, pressure, and resin content is significantly able to improve the IB. It is related closely with resin curing, decreasing of particle wetability, and increasing of particle surface area (Akbulut 1995 in Nemli 2002). Heinemann et al. (2002) described the difference IB properties using $10 \%$ UF resin in 5 temperature levels, there are two conceptual approaches to explain those phenomenon. First, temperature will affect of UF bonding in wood. Temperature will facilities the liquid accessed in wood, followed by acceleration diffusion of resin molecule in wood lumen. At low temperature, resin diffusion in wood will become lower that it will caused the decrease in mechanical interlocking. Second, pressing temperature affected the chemical substrats changes such as lignin melting, modification of hydrogen bonding that will increase the bonding strength value. Meanwhile pressing at low temperature reduced the mobility of polymer hydroxyl group. Unstable methyl ether bridge did not change to methylene bridge, consequently the bonding strength value is lower. In general, IB value had fulfill of JIS A 5908-2003 that requirement of minimum IB value is $1.3 \mathrm{~kg} \mathrm{~cm}^{-2}$.

\section{Conclusion}

Resin type, temperature and time of pressing in particleboard manufacturing were important factors to determine the quality of product. Based on physical and mechanical properties evaluation in particleboard, sorghum bagasse had potential value to be developed as raw material in particleboard manufacturing. Three types of resin used in this experiment were compatible to sorghum bagasse for particleboard manufacturing. Isocyanate was the best resin for resulting superior quality of particleboard made from sorghum bagasse.

\section{Acknowledgements}

We would like to express my sincerely thanks to Directorate General of Higher Education-Ministry of Education and Culture Republic Indonesia for supporting research fund by Competitive Research Grant (HIBAH BERSAING) 2013, SEAMEO-BIOTROP for supporting the raw material of sorghum bagasse.

\section{References}

[1] Bowyer, J.L. Shmulsky, J.G. Haygreen, Forest Products and Wood Science - An Introduction, Fourth edition. Iowa: Iowa State University Press, 2003

[2] C. Guler, Y. Copur, C. Tascioglu, The manufacture of particleboards using mixture of peanut hull (Arachis hypoqaea L.) and European black pine (Pinus nigra Arnold) wood chips, Bioresource Technology Vol 99, pp 2893-2897, 2008

[3] B.G. Heebink, W.F. Lehmann, F.V. Hefty, Reducing Particleboard Pressing Time:Exploratory Study, Research Paper FPL 180, U.S. Department of Agriculture Forest Service Forest Products Laboratory Madison, Wisconsin, 1972

[4] C. Heinemann, A. Fruhwald, P.E. Humphrey, Evaluation of Adhesive Cure During Hot Pressing of Wood-Based Composites, Proceeding of International Symposium on Wood Based Materials, Wood Composites and Chemistry, September 19-20, 2002 in Vienna, Austria

[5] [JSA] Japanese Standard Association. 2003. Japanesse Industrial Standard Particle Board JIS A 5908. Tokyo: Japanese Standard Association

[6] M.W. Kelly, Critical Literature Review of Relationship Between Processing Parameter and Physical Properties of particleboard, General Technical Report FPL-10, U.S. Department of Agriculture Forest Service and Forest Products Laboratory University of Wisconsin, 1977

[7] S.A. Lawal, B.I. Ugheoke, Investigation of Alpha-Cellulose Content of Agro-Waste Products as Alternatives for Paper Production, AU J.T. Vol.13(4), pp 258-260, 2010

[8] P. Malanit, M.C. Barbu, A. Fruhwald, The Gluability and Bonding Quality of An Asian Bamboo (Dendrocalamus asper) for The Production of Composite Lumber, J. Tropical Forest Science vol 21(4), pp 361-368, 2009 
[9] T.M. Maloney, Modern Particleboard and Dry-Process Fiberboard Manufacturing (updated edition), Miller Freeman, San Francisco, 1993

[10] G. Nemli, Factors Affecting The Production of E1 Type Particleboard. Turk J Agric For Vol.26, pp 31-36, 2002

[11] Supriyanto, Development of Sorghum for Food, Feed, and Energy . Booklet. SEAMEO BIOTROP, Bogor, Indonesia, 2011

[12] Supriyanto, Production of Liquid Organic Fertilizer Derived from Sorghum Waste in Ethanol Production. Research Proposal, SEAMEO BIOTROP, Bogor, Indonesia, 2012

[13] A. Thanapimmetha, K. Vuttibunchon, M. Saisriyoot, P. Srinophakun. Chemical and Microbial Hydrolysis of Sweet Sorghum Bagasse for Ethanol Production. Proceeding in
World Renewable Energy Congress 2011 at Sweden 8-13 May 2011, Linkoping, Sweden, 2011

[14] J.E. Winandy, A.M. Krzysik, Thermal Degradation of Wood Fibers During Hot-Pressing of MDF Composites: Part I: Relative Effects and Benefits of Thermal Exposure. Wood and Fiber Science Vol. 39(3), pp 450-461, 2007

[15] J.A. Youngquist. Wood-Based Composites and Panel Products, Wood Hand Book: Wood as an Engineering Material, Agric Handbook 72, Washington DC, US Department, 1999

[16] A.H. Iswanto. Characterization of Jatropha curcas L Fruit Hulls and Its Utilization to Produce High Quality Particle Board. Dissertation. Graduated School, Bogor Agricultural University, Indonesia, 2014 